J. Nat. Hist. Mus. Vol. 30, 2016-18 221-233

\title{
Status of herpetofauna in Rupandehi and Arghakhanchi districts, Nepal
}

\author{
Pit Bahadur Nepali ${ }^{1} \bowtie$ and Nanda Bahadur Singh ${ }^{2}$ \\ ${ }^{1}$ Tribhuvan Multiple Campus, Tribhuvan University, Palpa, Nepal \\ ${ }^{2}$ Central Department of Zoology, Tribhuvan University, Kirtipur, Kathmandu, Nepal \\ pitsnepal@gmail.com
}

\begin{abstract}
Herpetofauna are unique creature which comprise both amphibians and reptiles. The present study was carried out on herpetofaunal diversity in Rupandehi and Arghakhanchi districts. Each of six sampling stations was conducted in the study areas. Ten standardized $10 \times 200 \mathrm{~m}$ strip transects and 20-25 standard Quadrat sizes of $20 \mathrm{~m} \times 20 \mathrm{~m}$ were set in each station. Observed museum specimens and questionnaire survey were also conducted during data collection. A total of 45 spe cies of herpetofauna was recorded with 9 species of amphibians) and 36 species of reptiles. Six species were from the family Ranidae, two species from Bufonidae and one species from Rhacophoridae. Lizards were represented by 11 species belonging to four different families. Each of Gekkonidae, Agamidae and Scincidae family was represented by 3 species and the Varanidae by two species. The family Crocodylidae was represented by one species. The order Testudines (turtles) was represented by 2 species from family trionychidae and bataguridae. Twenty two species of snakes were recorded from 6 different families. The amphibian species, namely; Euphlyctis cyanophlyctis, Zakerana nepalensis, Bufo melanostictus and B. stomaticus and reptile species Calotes versicolor were relatively abundant. Seven species of amphibians and 18 species of reptiles were common in both districts. The study areas were diverse microhabitats due to the elevation from $71 \mathrm{~m}$ to $2004 \mathrm{~m}$ with plain, Churia and mountain range.
\end{abstract}

Keywords: Amphibian, diversity, richness, reptile

\section{INTRODUCTION}

Herpetofauna are poikilothermic tetrapods. Amphibians were represented by frogs, toads, caecilians and salamanders, whereas reptiles include crocodiles, turtles, tortoises, snakes and lizards. Many of them were dependent on terrestrial cum aquatic habitats and wetlands for some parts of their life cycles. Different habitats were needed for many life activities like nesting, hibernating, aestivating, dispersal, biological functions etc. Their microhabitats include lotic and lentic water, swamps, rocks and different vegetations.

Amphibians were known to be extremely variable as so many different morphs of the same species exist in all geographical variations (Barlett \& Barlett, 2003). Reptiles occupy and live in a great variety of aquatic and terrestrial habitats (Mc Diarmid et al., 2012) and there is interrelationship between terrestrial and neighboring wetlands (Gibbons, 2003).

The habitat modifications determine the quantitative and qualitative data of herpetofaunal biodiversity in particular areas. Many activities indispensable for human subsistence lead to 
biodiversity loss (Aerts et al., 2006; Diaz et al., 2006). Land-use change results in the decline of diversity (Lajmanovich et al., 2003; Storfer, 2003). Altitudinal gradients and the physical environment were prime factors that determine spatial and temporal distribution, abundance and richness patterns of organisms (Korner, 2000). Gibbons et al. (2000) reflects that decline of herpetofauna species diversity and population size can be attributed in part to causes including anthropogenic factors like habitat loss, and presence of invasive and introduced species, pollution, and disease.

Sri Lanka is very rich in herpetofauna and was included in the revised hot spots of the world with 55 species of herpetofauna belonging to 39 genera and 15 families (Mittermeier et al., 1998; Majumder et al., 2012). Grismer et al. (2010) as well as Das \& Norsham (2007) listed a total of 107 species of herpetofauna from Banjaran Bintang in Perak and that 600 herpetofauna species including 203 species of amphibians and 397 species of reptiles were from Peninsular Malaysia. Hasan \& Feeroz (2014) reported species diversity and habitat preferences in Bangladesh. A total of 32 amphibian species under 6 families had been reported from six protected areas of Bangladesh. The herpetofauna in Thummalapalle uranium mining areas resulted in a collection of 52 species belonging to 17 families. Snakes were the dominant group with 20 species (Reddy et al., 2013).

Nepal has variety of habitats due to presence of altitudinal variation with macro and micro habitats which are suitable for rich diversity of herpetofauna. Schleich and Kastle (2002) reported an account of 50 amphibians and 123 reptiles. At the same time, Shrestha (2001) reported that 206 species of herpetofauna including one species of salamander, one species of caecilians, 59 species of toad and frogs, 39 species of lizards, 81 species of snakes, two species of crocodiles, and 16 species of tortoise and turtles in Nepal. There was a total number of 138 species of reptiles from Nepal including 17 species of turtles, 2 species of crocodiles, 39 species of lizards and 80 species of snakes (Shah \& Tiwari, 2004). Bista (2010) carried out a survey in a Ramsar site of Nepal reporting 43 species of herpetofauna including 8 species of amphibians belonging to 3 families and 7 genera and 35 species of reptiles belonging to 13 families and 25 genera. Similarly the herpetofaual studies were carried out in different National parks of Nepal as well.

Very few species have been described from disturbed habitats, indicating a diminished species composition when compared with the original habitat (Molur, 2008). From a conservation point of view also, herpetofauna conservation efforts have been limited (Shah \&Tiwari, 2004). Despite these facts, the herpetofauna are poorly studied and determination of distribution, population status and habitat suitability for populations has not been carried out in these study areas so far. Therefore, the aim of this study is to identify and document the status as well as explore the venomous and non-venomous snakes of Rupandehi and Arghakhanchi districts of Nepal which helps to generate the current status of herpetofaunal species to current list, habitat situation, sensitization of the conservation efforts along with specie.s association analyses.

\section{MATERIALS AND METHODS}

\section{Study areas}

This study was undertaken in hilly Arghakhanchi and plain Rupandehi districts of Nepal. Twelve sampling stations were selected covering different habitats of these two districts (fig.1) 


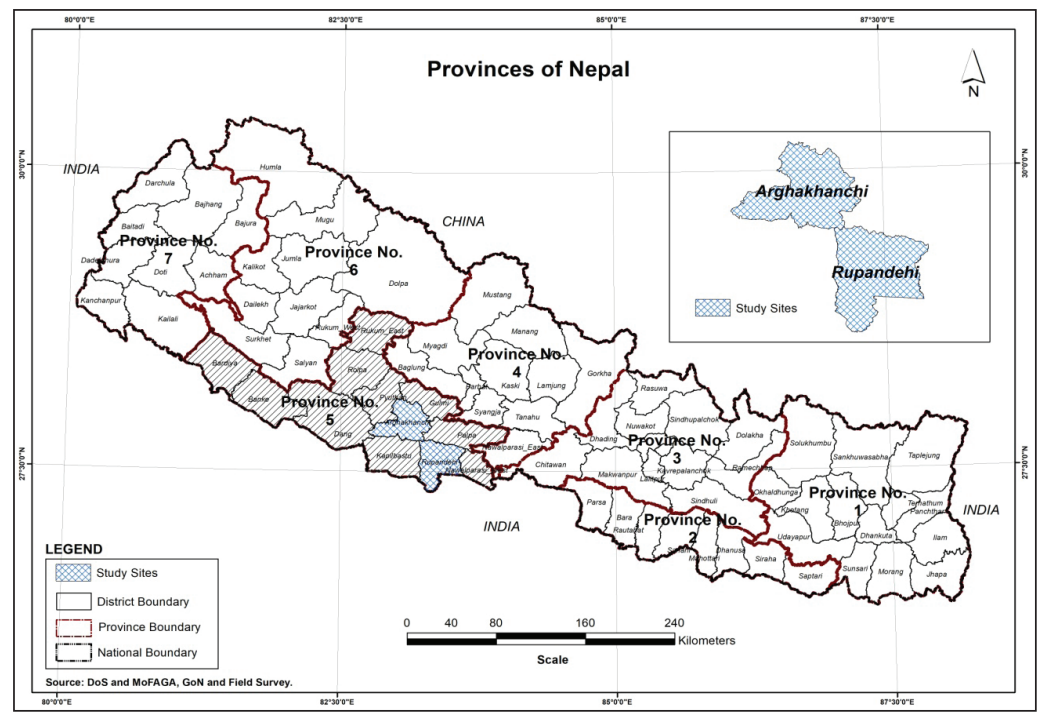

FIG. 1. Map of Nepal showing Arghakhanchi and Rupandehi districts in Province No. 5.

TABLE 1. Districts, stations, locations, elevations and habitat types in study areas.

\begin{tabular}{|c|c|c|c|c|}
\hline District & Stations & Locations & Elevations & Habitat types \\
\hline \multirow{6}{*}{ Arghakhanchi } & Sandhikharka & $\begin{array}{l}27^{0} 58^{\prime} .626^{\prime} \mathrm{N} \\
\& .83^{\circ} 07^{\prime} .385^{\prime} \mathrm{E}\end{array}$ & $935 \mathrm{~m}$ & $\begin{array}{l}\text { Agricultural fields, } \\
\text { wetlands, town areas } \\
\text { and community forest }\end{array}$ \\
\hline & Sitapur & $\begin{array}{l}28^{\circ} 00^{\prime} .256^{\prime} \mathrm{N} \& \\
83^{0} 10.281^{\prime} \mathrm{E}\end{array}$ & $906 \mathrm{~m}$ & $\begin{array}{l}\text { Subtropical forest, } \\
\text { few agricultural land, } \\
\text { village areas, riparian } \\
\text { vegetation, hilly areas }\end{array}$ \\
\hline & Gokhunga & $\begin{array}{l}28^{\circ} 06^{\prime} .125^{\prime} N \text { \& } \\
83^{\circ} 0.595^{\prime} \mathrm{E}\end{array}$ & $2004 \mathrm{~m}$ & $\begin{array}{l}\text { Agricultural lands, village } \\
\text { areas and community } \\
\text { forest, sloppy lands. }\end{array}$ \\
\hline & Arghatosh & $\begin{array}{l}28^{\circ} 0^{\prime} .25^{\prime} \mathrm{N} \& \\
83^{0} 10^{\prime} 195^{\prime} \mathrm{E}\end{array}$ & $890 \mathrm{~m}$ & $\begin{array}{l}\text { Riparian, community } \\
\text { and government forests, } \\
\text { agricultural lands and } \\
\text { small villages }\end{array}$ \\
\hline & $\begin{array}{l}\text { Pokharathok- } \\
\text { Khidimand }\end{array}$ & $\begin{array}{l}27^{0} 51^{\prime} .055^{\prime} \mathrm{N} \& \\
83^{0} 18.465^{\prime} \mathrm{E}\end{array}$ & $915 \mathrm{~m}$. & $\begin{array}{l}\text { Wetlands, community } \\
\text { and government forests, } \\
\text { agricultural lands and } \\
\text { small villages, hilly areas }\end{array}$ \\
\hline & Siddhara & $\begin{array}{l}27^{0} 49^{\prime} 21.11^{\prime} \mathrm{N} \& \\
82^{\circ} 50^{\prime} 58.1^{\prime} \mathrm{E}\end{array}$ & $460 \mathrm{~m}$ & $\begin{array}{l}\text { Riparian, Churia } \\
\text { range, tropical forest, } \\
\text { agricultural lands }\end{array}$ \\
\hline
\end{tabular}




\begin{tabular}{|c|c|c|c|c|}
\hline \multirow{6}{*}{ Rupendehi } & Khaireni & $\begin{array}{l}27^{0} 37^{\prime} .855^{\prime} \mathrm{N} \& \\
83^{\circ} 34.279^{\prime} \mathrm{E}\end{array}$ & $127 \mathrm{~m}$. & $\begin{array}{l}\text { Agricultural fields, small } \\
\text { urban areas, tropical } \\
\text { forest, plain }\end{array}$ \\
\hline & Belbas & $\begin{array}{l}27^{0} 41^{\prime} 525^{\prime} \mathrm{N} \& \\
83^{\circ} 26^{\prime} 436^{\prime} \mathrm{E}\end{array}$ & $147 \mathrm{~m}$ & $\begin{array}{l}\text { Plain to Churia range, } \\
\text { few agricultural lands } \\
\text { and small urban areas } \\
\text {,tropical forest }\end{array}$ \\
\hline & Gajedi & $\begin{array}{l}27^{\circ} 40^{\prime} .295^{\prime} \mathrm{N} \& \\
83^{\circ} 21.385^{\prime} \mathrm{E} .\end{array}$ & $107 \mathrm{~m}$. & $\begin{array}{l}\text { Agricultural fields, } \\
\text { wetland, small town, } \\
\text { small tropical forest, plain }\end{array}$ \\
\hline & Sainamaina & $\begin{array}{l}27^{0} 39^{\prime} .255^{\prime} \mathrm{N} \& \\
83^{0} 21.383^{\prime} \mathrm{E}\end{array}$ & $106 \mathrm{~m}$ & $\begin{array}{l}\text { Agricultural lands, village } \\
\text { areas, small forest and } \\
\text { plain }\end{array}$ \\
\hline & $\begin{array}{l}\text { Bhairahawa- } \\
\text { Madhulia: }\end{array}$ & $\begin{array}{l}27^{0} 30^{\prime} .655^{\prime} \mathrm{N} \& \\
83^{\circ} 24^{\prime} .595^{\prime} \mathrm{E}\end{array}$ & $71 \mathrm{~m}$. & $\begin{array}{l}\text { Agricultural fields, } \\
\text { riparian, urban areas, } \\
\text { plain }\end{array}$ \\
\hline & Chhapiya & $\begin{array}{l}27^{0} 30^{\prime} .377^{\prime} \mathrm{N} \& \\
83^{0} 12^{\prime} 599^{\prime} \mathrm{E}\end{array}$ & $79 m$ & $\begin{array}{l}\text { Agricultural fields, } \\
\text { wetlands, town areas, } \\
\text { plain }\end{array}$ \\
\hline
\end{tabular}

Data collections: In each station (table 1), the data collection was carried out by applying the different methods like transects, quadrats, visual encounter, spot light, catching etc. Samplings were carried out in the study sites, beginning from February 2016 till to the end of January 2017. The active search was carried out during the day time in selected sites. The samplings were taken in the mornings (approximately 9:00 a.m. to 12:00 p.m., depending on weather) and at nights (7:00 p.m. to 10:00 p.m.).

Surveys on herpetofauna were conducted in 10 standardized $10 \times 200 \mathrm{~m}$ strip transects, the number of which varied depending on patch size. Standard quadrat sizes of $20 \mathrm{~m} \times 20 \mathrm{~m}$ were set in different stations. Twenty quadrats were taken in mid hills and Chure regions and 25 quadrats were set randomly according to the type of locality in Terai region. Observation of museum specimens and questionnaire survey were also developed for data collection. The data were collected for each individuals of a species encountered during field work. The locality, date, time, weather condition, habitat, microhabitat and behavioral note were recorded in a field data sheet.

Specimens were captured for identification. Information recorded for each individual included species, snout-vent-length (SVL), tail length maximum, head width (HW), axilla-groin distance (AGD), fore-limbs (FL: axilla to tip of longest finger) and hind-limbs (HL: groin to tip of longest toe), and webbing formula etc. followed Anders \& Schleich (2002) and Rai (2003). Photographs were taken of representatives of each species and habitats. Geographic coordinates for each survey site were determined in the field with a Garmin GPS (etrex 10) receiver. Coordinates were recorded as latitude and longitude in decimal degrees.

Identification of the species was carried out by using the identification keys developed by field 
Nepali and Singh: Status of herpetofauna in Rupandehi and Arghakhanchi. .225

guide of Smith (1981), Dixon (2000), Schleich \& Kaestle (2002), and Rai (2003). Amphibian specimens were also identified with the aid of Bossuyt \& Dubois (2001), Dutta \& ManamendraArachchi (1996), Das (2008), Kabir et al. (2009) etc. The species encountered were identified using field guides and color photographs (Shah \& Tiwari, 2004).

\section{RESULTS AND DISCUSSION}

In this study, a total of 9 species of amphibians and 36 species of reptiles were recorded in study areas. In amphibians, 6 species were from the family Ranidae, two species from Bufonidae and one species from Rhacophoridae (table 2). Lizards were represented by 11 species belonging to four different families. In each family of Gekkonidae, Agamidae and Scincidae was represented by 3 species and Varanidae with two species. Order Testudines (turtles) was represented by 2 species from family trionychidae and bataguridae. Family Crocodylidae had species of Crocodylus palustris. Twenty two species of snake were recorded with five different families (table 3 ).

In Arghakhanchi district, there were 115 individuals of 8 amphibian species (two families and five genera) and 163 individuals of 26 reptile species ( 9 families and 22 genera). The amphibian species; Limnonectes teraiensis and reptile species Laudakia tuberculata, oligodon erythrogaster, Trachischium guentheri, Ramphotyphlops braminus, Oligodon arnensis, Hemibungarus macclellandii, Xenochrophis sanctjohannis, and Ovophis monticola were recorded in this district. Crocodylus palustris species recorded in small pond of Chure hill of this district.

A total of 88 individuals of 8 amphibian species under 3 families and 146 individual of 28 reptile species under 12 families and 21 genera were recorded from six stations of Rupandehi district. During the study, Pungshura smithii, Lissemys punctata, Varanus flavescens, Python molurus, Python bivittatus, Bungarus fasciatus, Naja kaouthia, and Naja naja were fairly recorded in this district.

The pond frog (Euphlyctis cyanophlyctis) and Cricket frog (Zakerana nepalensis) were relatively abundant in the study sites. The common Indian toad (Bufo melanostictus) and Bufo stomaticus (Marbled balloon frog) were commonly occurred. The tree frog (Polypedates leucomystax) was found in the forest and rocky areas. The snake belonged to five families, more number of snakes recorded from the family Colubridae ( 11 species) followed by Elapidae (5 species), Viperidae (2 species), Boidae (2 species), and Typhlopidae (1 species).

The lizard (Calotes versicolor), Rat snake (Ptyas mucosus) and Chichred keelback (Xenochrophis piscator) and Common wolf snake (Lycodon aulicus) were relatively common. Very rearly recorded species were Varanus flavescens, Python molurus, P. bivittatus, Pungshura smithii, Lissemys punctata, Dendrelaphis tristis, Oligodon erythrogaster, $\mathrm{O}$. arnensis, Trachischium guentheri, and Xenochrophis sanctjohannis.

In the reported 22 species of snakes, seven species (2 families of Elapidae and Viperidae) were venomous. The common venomous snakes recorded were Bungarus caeruleus, $B$. fasciatus, Hemibunarus macclellandii, Naja kaouthia, Naja naja, Trimeresus albolabris, and Ovophis monticola. Fifteen non-venomous species recorded in the present study were Python 
molurus, P. bivittatus, Ramphotyphlops braminus, Amphiesma stolatum, Boiga trigonata, Coelognathus helena, C. radiates, Dendrelaphis trisis, Lycodon aulicus, Oligodon arnensis, Oligodon erythrogaster, Ptyas mucosa, Trachischium guentheri, Xenochrophis piscator, and Xenochrophis sanctjohannis.

The Bufo stomatictus and B. melanostictus were found in arid habitats and Polypedates leucomystax was an arboreal species recorded during the study. Ocock, et al. (2016) reported similar habitat of tree frog which had specialized toe-discs for climbing and a relatively high resistance to water-loss. The Euphlyctis spp. and Hoplobatrachus spp. preferred aquatic habitat, while the remaining species of amphibians were found in semi-aquatic and shady habitats. A similar biology was explained by Andreone $(1993,1994)$ taking into account the scarcity of still water bodies at the analysed sites, and therefore to a local rarity of this species, elsewhere almost abundant. According to Omogbai et al. (2002), populations of amphibians were excess during the rainy season. Amphibians presented their highest diversity where they had spent most of their evolutionary history (Alexandra \& Troumbis, 1997). Aryal et al. (2010) reported Turtle trade surveys conducted in the markets mainly in Kailali, Kapilbastu, Rupandehi, Nawalparasi, Sunsari and Saptari districts and 16 species were reported the status of species distributions and incorporating the turtles in conservation issues. In the present study Pungshura smithii and Lissemys punctata were recorded from study sites.

Abundantly encounter species found to be were Calotes versicolor, Hemidactylus brookii, H. flaviviridis, Eutrophis carinata, Coelognathus helena, C. radiates, Lycodon aulicus, Ptyas mucosa, Xenochrophis piscator, Trimeresurus albolabris, Bufo melanostictus, B. stomaticus, Euphlyctis cyanophlyctis and Hoplobatrachus tigerinus. Shah (1998) prepared a checklist of herpetofauna of Nepal in which he recorded 64 snake species. Similarly, Shah \& Tiwari (2004) reported abundantly available species Euphlyctis cyanophlyctis and Calotes versicolor in Nepal. The diversity of herpetofauna in the study area was reflected in species richness due to wide range of temperature, diverse topography, land use and diverse microhabitat. Diversity of herpetofuna is high due to land of topographic contrast climate and water condition etc. A total of 45 species of herpetofauna were recorded in which 9 species of amphibians (6 genera, and 3 families) and 36 species of reptiles (27 genera, 12 families, and 3 suborders).In Arghakhanchi district, there were 115 individuals of 8 amphibian species including 2 families with 5 genera and 162 individuals of 25 reptile species (22 genera and 10 families). In Rupandehi district, a total of 88 individual of amphibian under 8 species (5 genera and 3 families) and 146 individual of reptile under 28 species ( 21 genera and 10 families) were recorded. Out of 9 amphibian species, 7 species were common in both district but Limnonectes teraiensis was only found in Arghakhanchi and Polypedates leucomystax was only found in Rupandehi district. A total of 36 reptile species, 18 species were common in both sites but 8 species were only recorded in Arghakhanchi and other 10 species were only found in Rupandehi district.

The Euphlyctis cyanophlyctis, Zakerana nepalensis, Bufo melanostictus and B. stomaticus were relatively abundant in study sites. The most common reptile species was Calotes versicolor. The species richness of reptiles was found to be more in Rupandehi than in Arghkhanchi district. Habitat type may be a main contributing factor on major effect on species richness, 
Nepali and Singh: Status of herpetofauna in Rupandehi and Arghakhanchi. .227

diversity, distribution and abundance of amphibians and reptiles of study sites. Amphibian species were recorded in aquatic, semi-aquatic and shady habitats and found active in rainy season. On the other hand, the main habitats of reptiles were forests, grasslands, trees, tunnels, cliffs, rocks, different aquatic bodies, agricultural lands and human dwellings. There were 22 species of snakes in which 7 species were venomous species under 2 families (Elapidae and Viperidae) and 15 non-venomous species under 3 families (Boidae, Colubridae and Typhlopidae). Out of 7 venomous species, 2 species were common in both districts but 2 species were recorded in Arghakhanchi and 3 species were recorded in Rupandehi district. A total of 15 non-venomous species, 7 species were common in both districts while 5 species in Arghakhanchi and 3 species in Rupandehi districts were recorded.

\section{ACKNOWLEDGMENTS}

This research was supported by the University Grants Commission (UGC), Sanothimi, Bhaktapur, Nepal. We express our gratitude to Prof. Karan Bahadur Shah for his cooperation in the identification of species, preservation techniques and guidance. We are also indebted to Mr. Radheshyam Nepali, Thakur Prasad Poudel, Gun Bahadur Gharti for their help during field visits.

\section{REFERENCES}

AERTS, R; OVERTVELD, K V; HAILE, M; DECKERS, J; MUYS, B (2006) Species composition and diversity of small Afromontane forest fragments in northern Ethiyopia. Springer Science 187:127-142.

ALEXANDRA, M; TROUMBIS, A Y (1997) Aspects of heterogeneity in the distribution

of diversity of the European herpetofauna. Acta Oecologica 18 (4): 393-412.

ANDREONE, F (1993) Kommentierte Liste von Amphibienfunden auf Madagaskar. Salamandra 29 (3/4): 200-211.

ANDREONE, F (1994) The amphibians of Ranomafana rain forest, Madagascar-preliminary community analysis and conservation considerations. Oryx 28(3): 207-214.

ARYAL, P C; DHAMALA, M K; BHURTEL, B P; SUWAL, M K; RIJAL, B (2010) Species accounts and distribution of Turtles with notes on exploitation and trade in Tarai, Nepal. The first national youth conference on environment (NYCE-I). Kathmandu, Nepal, Caron.

BHUJU, U R; SHAKYA, P R; SHRESTHA, T B; SHRESTHA, S (2007) Nepal biodiversity resource Book: Protected Areas, Ramsar Sites, and World Heritage Sites. International Center for Integrated Mountain Development (ICIMOD) and Ministry of Environment, Science and Technology-Government of Nepal (MoEST/GON) Prepared by Nepalnature.com, Kathmandu, Nepal.

BRANCH, B (2005) Snakes, other reptiles and amphibians of east Africa. Cape Town, South Africa: Struik Nature 144.

BARLETT, P P; BARLETT, R D (2003) Reptiles and amphibians of the Amazon: An ecotourist's guide. Florida University Press, U.S.A.

BOSSUYT, F; DUBOIS, A (2001) A review of the frog genus Philautus Gistel, 1848 (amphibia, anura, ranidae, rhacophorinae). Zeylanica 6(1): 1-122.

CNP (Chitwan National Park) (2014) Babarmahal, Kathmandu, Nepa: Department of national park and wildlife conservation. 
DAS, A (2008) Diversity and distribution of herpetofauna and evaluation of conservation status in Barail Herpetofauna Project, Conservation status in Barail Hill Range (including Barail Wildlife Sanctuary), Aaranyak Guwahati, Assam, India; 94 pp.

DIRZO, R; RAVEN, P H (2003) Global state of biodiversity and loss. Annual review of environmental resources 28: 137-167.

DIXON, J R (2000) Amphibians and reptiles of Taxas. Taxas: A \& M Universiy Press, U.S.A.

DUTTA, S K; MANAMENDRA-ARACHCHI, K (1996) The Amphibian fauna of Sri Lanka. Colombo Wildlife heritage trust of Sri Lanka, Sri Lanka; 232 pp.

FRENCH, D D (1994) Hierarchical richness index (HRI): a simple procedure for scoring 'Richness', for use with grouped data. Biological Conservation 69: 207-212.

GIBBONS, J W (2003) Terrestrial habitat: A vital component for herpetofauna of isolated wetlands. Wet lands 23 (3): 630-635.

GRISMER, L L; ONN, C K; GRISMER, J L;WOOD, P L JR.; NORHAYATI, A (2010) A checklist of the herpetofauna of the Banjaran Bintang, Peninsular Malaysia. Russian Journal of Herpetology 17 (2): 147160.

HASAN, M K; FEEROZ, M M (2014) Species diversity and habitat preferences of amphibian fauna in six protected areas of Bangladesh. Department of Zoology, Jahangirnagar University, Savar, Dhaka, Bangladesh. J. Zool. 42(1): 105-116.

KABIR, S M H; AHMED, M; AHMED, A T A; AHMED, Z U; BEGUM, Z N T; HASSAN, M A; KHONDOKER, M (eds) (2009) Amphibians and Reptiles: Asiatic Society of Bangladesh, Dhaka. Encyclopedia of flora and fauna of Bangladesh 25: 204.

LAJMANOVICH, R C; SANDOVAL, M T; PELTZER, P M (2003) Induction of mortality and malformation in Scinax nasicus tadpoles exposed by glyphosate formulations. Bulletin of environmental contamination and toxicology 70: 612-618.

MAGURRAN, A E (2004) Measuring Biological Diversity. Blackwell Science, Oxford, U.K.

MAJUMDER, J; BHATTACHARJEE, P P; MAJUMDAR, K; DEBNATH, C; AGARWALA, B K (2012) Documentation of herpetofaunal species richness in Tripura, northeast India. NeBIO I www.nebio.in I, 3 (1): 60-70.

MITTERMEIER, R A; MYERS, N; THOMSEN, J B; FINESSE, G A B; OLIVIERI, S (1998) Biodiversity hotspots and major tropical wilderness areas: approaches to setting conservation priorities. Conservation Biology 12 (3): 516-520.

OCOCK, J F; KINGSFORD, R T; PENMAN, T D; ROWLEY, J J L (2016) Amphibian abundance and detection trends during a large flood in a semi-arid floodplain wetland. Herpetological Conservation and Biology 11: 408-425.

ORTIZ-YUSTY, C E; PAEZ, V; ZAPATA, F A (2013) Temperature precipitation complements de prediction de la request de species de amphibious del Norte de los Andersen Colombia. Caldasia 35(1): 65-80.

RAI, K R (2003) Environmental impacts, systematic and distribution of herpetofauna from east Nepal Central Department of Zoology, Institute of Science and Technology, Tribhuvan University Kirtipur, Kathmandu, Nepal (Unpublished Doctoral Dissertation).

REDDY, Y A; SADASIVAIAH, B; INDIRA, P; PULLAIAH, T (2013) Herpetofauna of Thummalapalle uranium mining areas: Andhra Pradesh, India. International Journal of Biodiversity and Conservation 
Nepali and Singh: Status of herpetofauna in Rupandehi and Arghakhanchi

5(8): 515-522.

SCHLEICH, H H; KASTLE, W (2002) Amphibians and reptiles of Nepal: Biology, Systematic, Field Guide. A. R. G. Gantner Verlag Kommanditgeselschaft, FL 9491 Ruggell, Germany; 1201 pp.

SCHENIDER, R L; KRASNY, M E; MORREALE, S J (2001) Hands-on herpetology: exploring ecology and conservation. NSTA press, Arlington, Virginia, U. S. A.

SHAH, K B; TIWARI, S (2004) Herpetofauna of Nepal: conservation companion. IUCN Nepal.

SMITH, M A (1981) The fauna of British India, Ceylon and Burma. Today and Tomorrow's Printers and Publishers III, New Delhi, India.

STORFER, A (2003) Amphibian declines: future directions. Diversity and Distribution 9: 151-163.

THAPA CHHETRY, D (2010) Diversity of herpetofauna in and around the Koshi Tappu Wildlife Reserve. Bibechana 6.

URBINA-CARDONA, J N; OLIVWERES-PE'REZ, M; REYNOSO, V H (2006) Herpetofauna diversity and microenvironment correlates across a pasture-edge-interior ecotone in tropical rain forest fragments in the Los Turtles Biosphere Reserve of Veracruz, Mexico. Biological conservation 132(1): $61-75$.

WWF (2011) Wet land factsheet series Khaptad Daha \& Tribeni wetland system: Khaptad National Park, Kathmandu, Nepal. WWF Nepal. 


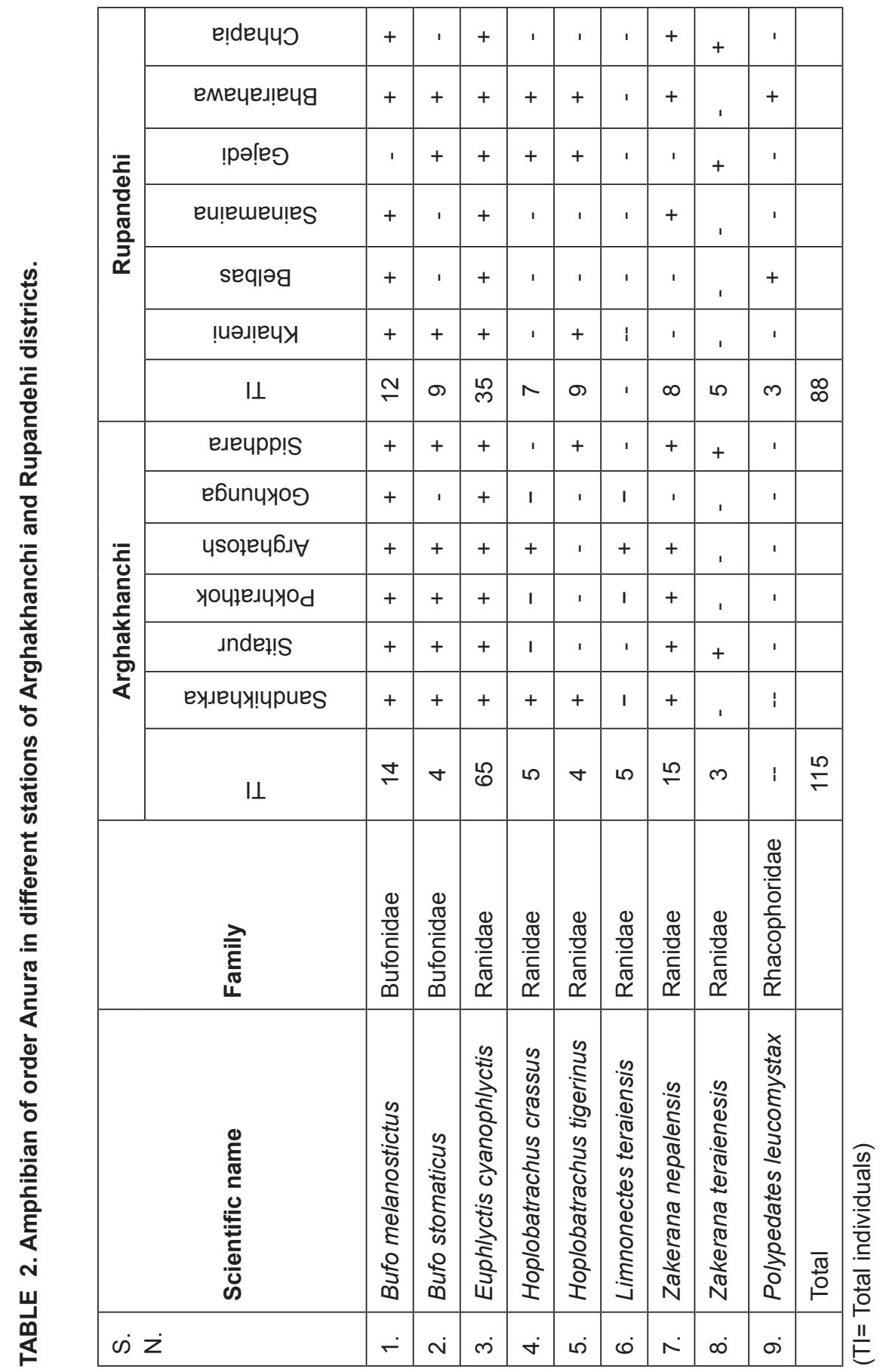


Nepali and Singh: Status of herpetofauna in Rupandehi and Arghakhanchi.

\begin{tabular}{|c|c|c|c|c|c|c|c|c|c|c|c|c|c|c|c|c|c|}
\hline \multirow{7}{*}{ 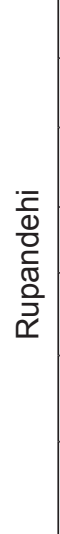 } & е!̣deч૫つ & + & + & + & & ' & ' & ' & ' & ' & + & + & ' & 1 & , & , & , \\
\hline & емечедіечя & + & ' & + & ' & ' & + & + & + & ' & + & ' & + & ' & I & I & I \\
\hline & !pə!eə & ' & + & + & ' & ' & ' & + & ' & ' & ' & + & ' & ' & I & 1 & I \\
\hline & eu!emeuịes & ' & ' & + & ' & ' & + & ' & + & ' & + & ' & ' & ' & 1 & I & I \\
\hline & seq|əg & ' & ' & + & ' & + & ' & + & + & ' & ' & ' & + & ' & 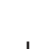 & + & + \\
\hline & !ుәџ!ечપ્ર & ' & ' & + & ' & ' & + & + & ' & $\mathrm{i}$ & ' & ' & ' & + & & & + \\
\hline & $I \perp$ & $\sim$ & $\sim$ & $\bar{m}$ & ' & $\sim$ & $\overleftarrow{\sim}$ & a & $\infty$ & - & 10 & 0 & $N$ & $\leftarrow$ & I & $N$ & $\sim$ \\
\hline \multirow{7}{*}{ 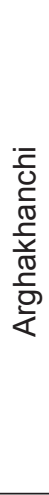 } & елечрp!S & ' & ' & + & 1 & ' & ' & + & ' & ' & ' & + & + & ' & + & I & I \\
\hline & eбunyশ્ર0כ & ' & ' & + & + & ' & 1 & ' & ' & 1 & ' & ' & ' & ' & , & , & , \\
\hline & чsoleubı & ' & ' & + & ' & + & + & ' & ' & + & ' & ' & + & ' & I & I & I \\
\hline & уочоредчуод & ' & ' & + & ' & ' & 1 & ' & ' & 1 & + & ' & + & ' & I & I & I \\
\hline & undet!S & ' & ' & + & ' & ' & 1 & ' & ' & ' & + & + & ' & ' & I & I & I \\
\hline & еулечપ્ર!чрues & ' & ' & + & ' & + & + & + & ' & 1 & + & ' & + & ' & 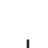 & 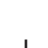 & t \\
\hline & $I \perp$ & ' & ' & లి & $\stackrel{2}{2}$ & $m$ & $\stackrel{m}{\longrightarrow}$ & $\mp$ & ' & 10 & $\infty$ & $\nabla$ & $\lambda$ & ' & 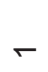 & I & I \\
\hline & $\begin{array}{l}\stackrel{\widehat{\bar{E}}}{\overrightarrow{\widetilde{\sigma}}} \\
\stackrel{\leftarrow}{ }\end{array}$ & $\begin{array}{l}\mathbb{0} \\
\frac{\pi}{0} \\
\frac{0}{5} \\
\frac{\pi}{\pi} \\
\frac{\pi}{\pi} \\
\infty\end{array}$ & 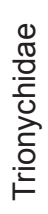 & $\begin{array}{l}\frac{0}{\pi} \\
\frac{\pi}{0} \\
\frac{0}{E} \\
\frac{\pi}{0} \\
\frac{0}{2}\end{array}$ & $\begin{array}{l}\frac{1}{\pi} \\
\frac{0}{0} \\
\frac{\mathbb{E}}{\pi} \\
\frac{\pi}{2} \\
\end{array}$ & 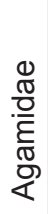 & 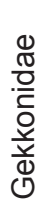 & 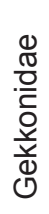 & 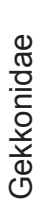 & $\begin{array}{l}\frac{1}{\pi} \\
\frac{0}{0} \\
\frac{\mathrm{C}}{0} \\
\text { c }\end{array}$ & $\begin{array}{l}0 \\
\frac{0}{0} \\
\frac{0}{0} \\
. \frac{5}{0} \\
\text { D }\end{array}$ & $\begin{array}{l}0 \\
\frac{\pi}{0} \\
\frac{0}{0} \\
\frac{\pi}{0} \\
\mathscr{c}\end{array}$ & $\begin{array}{l}\frac{1}{\pi} \\
\frac{0}{0} \\
\frac{0}{0} \\
\text { c }\end{array}$ & $\begin{array}{l}0 \\
\frac{\pi}{0} \\
\frac{0}{0} \\
\frac{\bar{O}}{0} \\
\mathcal{C}\end{array}$ & 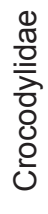 & $\begin{array}{l}\frac{1}{\pi} \\
\frac{\pi}{0} \\
\frac{0}{0}\end{array}$ & $\begin{array}{l}\frac{0}{\pi} \\
\frac{\pi}{0} \\
\frac{0}{0}\end{array}$ \\
\hline & 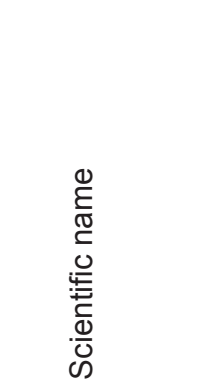 & 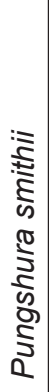 & 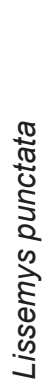 & 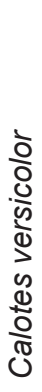 & 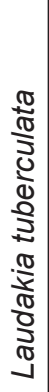 & 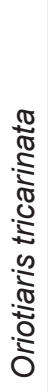 & 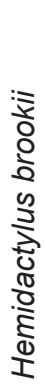 & 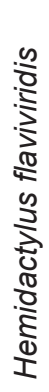 & 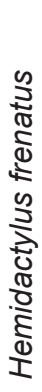 & 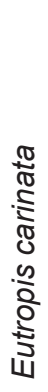 & 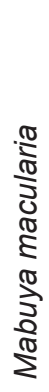 & 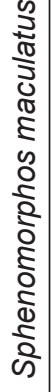 & 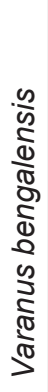 & 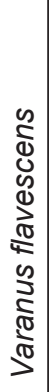 & 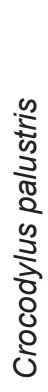 & 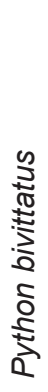 & 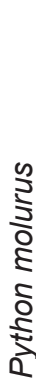 \\
\hline & ci $z$ & 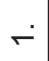 & N & $\dot{m}$ & $\dot{\nabla}$ & $\omega^{\circ}$ & $0^{\circ}$ & $\sim$ & $\infty$ & $\sigma^{\circ}$ & 우 & $\mp$ & 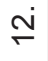 & $\stackrel{m}{\square}$ & $\stackrel{+}{\check{2}}$ & $\stackrel{\circ}{\circ}$ & $\stackrel{6}{\circ}$ \\
\hline
\end{tabular}




\begin{tabular}{|c|c|c|c|c|c|c|c|c|c|c|c|c|c|c|c|c|c|c|c|c|}
\hline 1 & + & ' & ' & 1 & + & ' & I & + & ' & + & ' & ' & ' & ' & ' & + & ' & + & ' & \\
\hline+ & + & + & ' & ' & + & ' & ' & + & ' & + & ' & ' & + & + & ' & + & + & + & ' & \\
\hline+ & ' & ' & + & ' & ' & ' & ' & + & ' & + & + & ' & + & ' & ' & ' & ' & + & ' & \\
\hline ' & + & ' & ' & ' & ' & ' & ' & + & ' & ' & ' & ' & + & ' & ' & ' & + & ' & ' & \\
\hline I & ' & + & ' & 1 & + & ' & ' & + & ' & ' & ' & ' & ' & ' & ' & ' & ' & + & ' & \\
\hline+ & ' & ' & + & + & + & ' & ' & + & ' & + & ' & ' & + & ' & ' & ' & + & + & ' & \\
\hline$\nabla$ & $m$ & $\nabla$ & $m$ & - & $\nabla$ & ' & ' & $\sigma$ & ' & ما & $r$ & ' & م & - & 1 & $\sim$ & $\nabla$ & 0 & ' & $\stackrel{\mathcal{O}}{\sim}$ \\
\hline I & ' & + & + & I & ' & ' & ' & + & ' & ' & ' & ' & + & ' & ' & ' & & ' & & \\
\hline ' & ' & + & ' & ' & ' & ' & ' & + & + & ' & ' & ' & ' & ' & + & ' & & ' & + & \\
\hline+ & + & ' & ' & ' & ' & ' & ' & + & ' & + & ' & ' & ' & ' & ' & ' & & + & ' & \\
\hline I & ' & I & + & I & + & ' & + & + & ' & + & ' & ' & ' & ' & ' & I & & + & 1 & \\
\hline ' & ' & + & + & ' & + & ' & ' & + & ' & + & + & ' & ' & ' & ' & ' & & + & ' & \\
\hline+ & + & + & ' & ' & + & + & 1 & + & ' & + & ' & + & + & ' & ' & ' & & + & ' & \\
\hline$m$ & $m$ & $\bullet$ & 10 & ' & م & 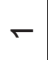 & - & $\mp$ & - & $\nabla$ & $r$ & $\sim$ & $\sim$ & ' & $\sim$ & ' & ' & $\infty$ & $\sim$ & 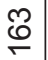 \\
\hline $\begin{array}{l}\frac{1}{\pi} \\
\frac{\pi}{0} \\
\frac{0}{2} \\
\frac{3}{0} \\
0\end{array}$ & $\begin{array}{l}\frac{1}{\pi} \\
\frac{\pi}{0} \\
\text { 을 } \\
\frac{3}{0} \\
0 \\
0\end{array}$ & 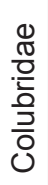 & $\begin{array}{l}\frac{1}{\pi} \\
\frac{\pi}{0} \\
\frac{0}{0} \\
\frac{3}{0} \\
0\end{array}$ & $\begin{array}{l}\frac{1}{\pi} \\
\frac{\pi}{0} \\
\frac{0}{2} \\
\frac{\partial}{0} \\
0 \\
0\end{array}$ & $\begin{array}{l}\frac{1}{\pi} \\
\frac{\pi}{0} \\
\frac{0}{2} \\
\frac{3}{3} \\
0 \\
0\end{array}$ & $\begin{array}{l}\frac{1}{\pi} \\
\frac{\pi}{0} \\
\text { 을 } \\
\text { 응 } \\
0\end{array}$ & $\begin{array}{l}\frac{0}{\pi} \\
\frac{\pi}{0} \\
\frac{0}{2} \\
\frac{3}{0} \\
0\end{array}$ & $\begin{array}{l}\frac{1}{\pi} \\
\frac{\pi}{0} \\
\text { 을 } \\
\text { 응 }\end{array}$ & $\begin{array}{l}\frac{1}{\pi} \\
\frac{\pi}{0} \\
\text { 을 } \\
\text { 응 } \\
0\end{array}$ & $\begin{array}{l}\frac{1}{\pi} \\
\frac{\pi}{0} \\
\text { 은 } \\
\text { 응 } \\
0\end{array}$ & $\begin{array}{l}0 \\
\frac{\pi}{0} \\
\frac{0}{0} \\
\frac{0}{3} \\
0 \\
0\end{array}$ & $\begin{array}{l}\frac{0}{\pi} \\
\frac{\pi}{0} \\
\frac{0}{2} \\
\frac{0}{2} \\
\frac{0}{2} \\
\frac{1}{2}\end{array}$ & 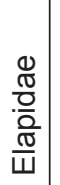 & $\begin{array}{l}\frac{0}{\pi} \\
\frac{\pi}{0} \\
\frac{0}{0} \\
\end{array}$ & $\begin{array}{l}\frac{0}{\pi} \\
\frac{\pi}{0} \\
\frac{\pi}{\pi}\end{array}$ & $\begin{array}{l}\frac{0}{\pi} \\
\frac{0}{2} \\
\frac{\pi}{\frac{\pi}{0}}\end{array}$ & 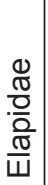 & $\begin{array}{l}\frac{0}{\pi} \\
\frac{0}{0} \\
\frac{0}{0} \\
\stackrel{0}{\frac{2}{2}}\end{array}$ & $\begin{array}{l}\frac{1}{\pi} \\
\frac{\pi}{0} \\
\frac{0}{2} \\
\stackrel{2}{2} \\
>\end{array}$ & \\
\hline $\begin{array}{l}\frac{5}{3} \\
\frac{\pi}{\sigma} \\
\frac{2}{2} \\
\omega \\
\frac{0}{2} \\
\frac{1}{5} \\
. \frac{1}{5} \\
\frac{2}{2} \\
\frac{1}{4}\end{array}$ & 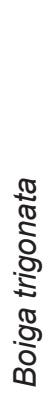 & 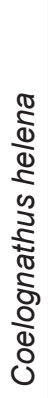 & 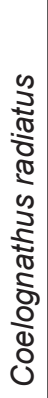 & 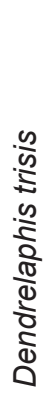 & 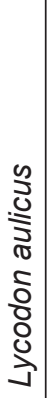 & 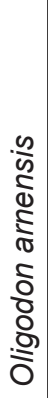 & 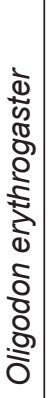 & 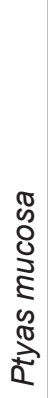 & 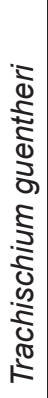 & 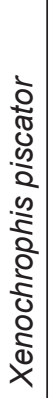 & 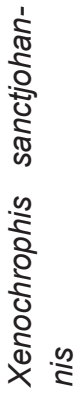 & 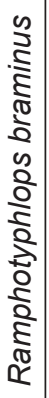 & 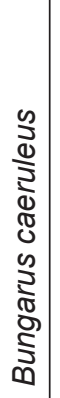 & 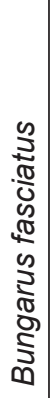 & 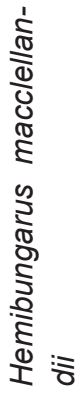 & $\begin{array}{l}\frac{\pi}{2} \\
\frac{\pi}{3} \\
\frac{\pi}{\pi} \\
\frac{\pi}{\pi} \\
\frac{\pi}{2}\end{array}$ & $\begin{array}{l}\cdot \frac{\pi}{\sigma} \\
\frac{\pi}{\sigma} \\
\frac{\pi}{2}\end{array}$ & 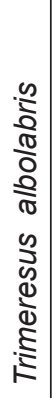 & 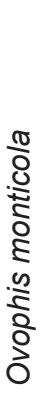 & $\begin{array}{l}\bar{\pi} \\
\text { రై } \\
\end{array}$ \\
\hline$\stackrel{\Sigma}{\sigma}$ & $\stackrel{\infty}{\infty}$ & $\stackrel{\circ}{\circ}$ & $\stackrel{N}{ }$ & $\dot{\sim}$ & N & 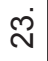 & $\stackrel{ \pm}{\sim}$ & $\stackrel{2}{\sim}$ & $\stackrel{\oplus}{\sim}$ & $\grave{N}$ & $\stackrel{\infty}{\sim}$ & ঠे & ச্ল & $\dot{m}$ & ๗ై & लెं & ர் & ம் & $\dot{m}$ & \\
\hline
\end{tabular}


Nepali and Singh: Status of herpetofauna in Rupandehi and Arghakhanchi.

.233

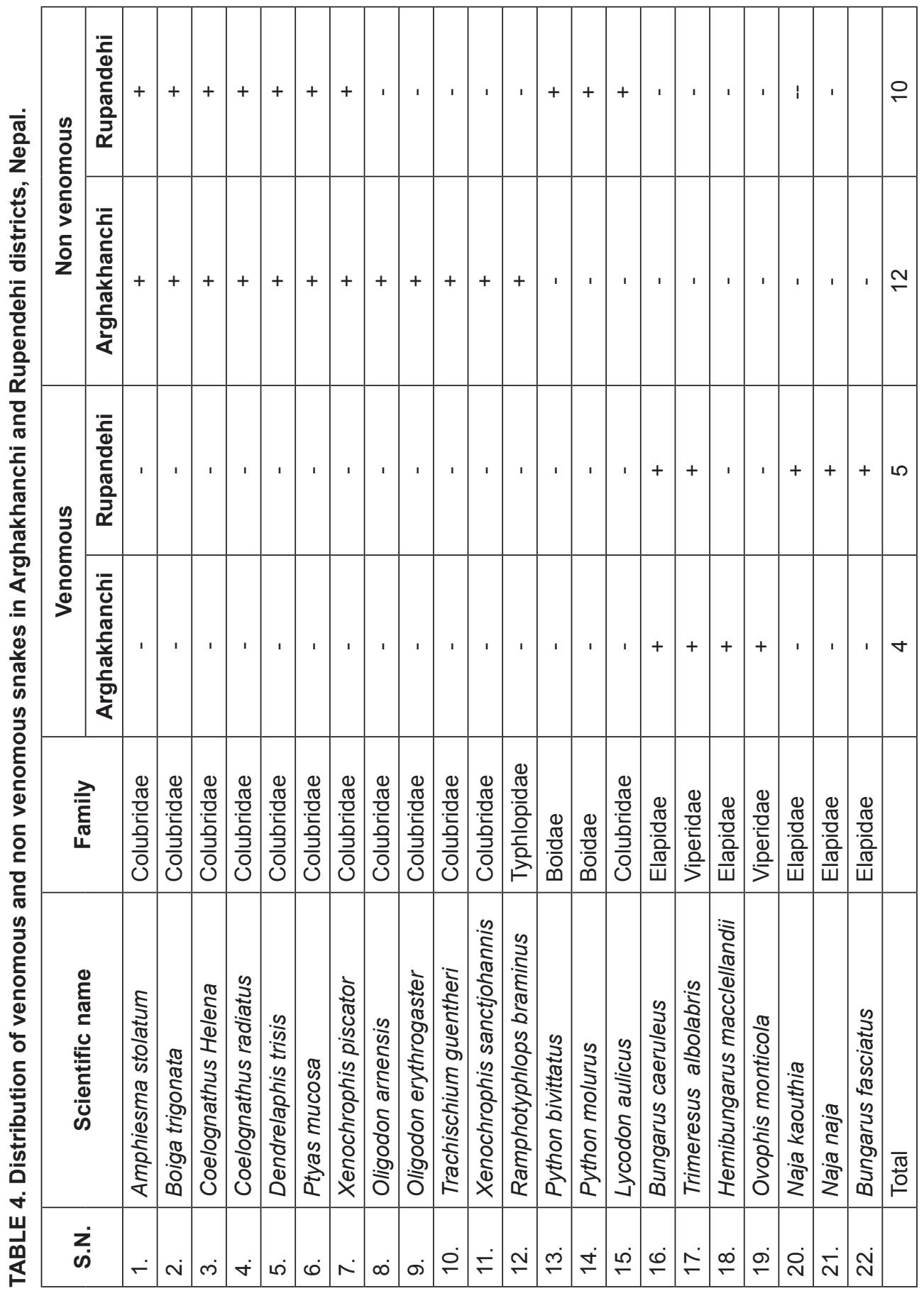

